\title{
Privatisation and commercialisation in Nigeria: Implications and prospects for good governance
}

\author{
T.O. Asaolu*, O. Oyesanmi and P.O. Oladele \\ Department of Management and Accounting, Obafemi Awolowo University. \\ Ile-Ife, Nigeria \\ twasaolu@yahoo.co.uk \\ A.M. Oladoyin \\ Department of Public Administration, Obafemi Awolowo University, \\ Ile-Ife, Nigeria \\ Received November 2004
}

\begin{abstract}
The privatisation and commercialisation Decree No. 25 of 1988 (amended 1999) which provided the legal backing for the Technical Committee of Privatisation and Commercialisation (TCPC), began the major paradigm shift in the conceptualisation of public enterprises in Nigeria. The paper primarily examined the privatisation exercise in Nigeria since 1988. It also attempted to provide measures that will simplify the complex process of privatisation with the hope of lessening the probability of crisis. The paper considered the impact of privatisation on performance of privatised companies, changes in employment and the increase in the prices of commodities of the enterprises vis-à-vis their gross income towards the overall good governance of the Nigerian society.
\end{abstract}

The data for the paper were mainly secondary; and were drawn from the financial statements of companies in the stock Exchange and other stock Exchange reports, Central Bank Bulletins, publications and published reports of the Bureau of Public Enterprises. Newspapers and publication of the Federal Office of Statistics are other sources. The data were analysed by trend analysis using absolute figures, percentages and ratios based on the past record on privatisation in Nigeria.

However, the study discovered that only a few successful enterprises, Flour Mills, African Petroleum, National oil and Chemical Marketing Company Limited (NOLCHEM) were partially privatised. The commercialisation of enterprises such as National Electric Power Authority (NEPA), Nigeria Telecommunications (NITEL) and Nigerian National Petroleum Corporation (NNPC), hardly showed any significant improvement in their operational and economic performance.

The papers showed that employment levels were affected by privatisation. Between 1989 and 1993, the public sector accounted for more job losses than privatised companies. When privatised firms employment rose, public and private sectors still had lower employment levels. The sharp increase in prices between 1992 and 1994 did not create a sufficient increase in gross earnings for 1994. The results revealed that a reduction in public control would have an effect (at least in the short term) on prices. Profits increase but the extent to which this increase can attributed to reduction of government controls is not clear. Three banks witnessed sharp increase in investments and profitability immediately after privatisation, and there was a slight decrease before another increase. Results showed that privatisation has improved company performance, especially in the efficiency of resources utilisation. Higher profit to capital employed ratios has been witnessed since privatisation. Debt/Total Asset ratios have not been affected in any adverse way. Results from the study also revealed that price increases in excess of $200 \%$ occurred immediately after privatisation. This perhaps has an effect on the profits of the companies (especially those that still maintained monopoly status for a while.

However, one fact is clear: the heydays of public enterprises in Nigeria are gone for good. It was on this note that the study concluded that privatisation is the appropriate economic recipe to achieve the much desired human development and good governance.

*To whom all correspondence should be addressed.

\section{Introduction}

Since 1988, the term privatisation has become a common one in business and policy circles in Nigeria. Yet, it may be said that not too many people outside these circles understand what it means and what its attendant implications concerning economy and governance of the society would be. This is so because $61 \%$ of adult Nigerians are illiterates (EFA, 2005: 268). Besides, 90,8\% of Nigerians between 1990 and 2001 live on less \$2 per day (EFA, 2005: 261). This implies that most Nigerians are actually ignorant of the contents and implications of the 
privatisation programme per se; unfortunately, even the literate few are either poor (a situation, which excludes them from participation in the exercise) or are generally overwhelmed and flabbergasted by the globalisation arguments.

As far back as 1776, Adam Smith had stated the macroeconomic and microeconomic benefits of transferring control and ownership rights from public to private sector, that is, privatisation. As privatisation becomes entrenched in many parts of the globe, calls for its implementation in the developing countries, especially by International Financial Institution (IFIs) increase every day. For instance an IMF Team, which visited Nigeria in 1999, offered the nation a $\$ 1$ billion loan conditional on the implementation of certain reform measures, including privatisation of ailing parastatals and Nigeria has since accepted the loan.

The interest of Nigerian administration under Olusegun Obasanjo is inclined towards privatisation and the basic argument in support of the position is that government should leave the economy in the hands of the ever-efficient market forces. In other words, proponents of privatisation state that privatisation will inter alia

1. lead to a more equitable distribution of wealth;

2. ensure greater efficiency in the running of enterprises as government bottlenecks are removed;

3. reduce the Public Sector Borrowing Requirement (PSBR);

4. raise money for cash strapped governments; and

5. increase consumer rights.

Those who oppose privatisation fear that privatisation may simply mean a replacement of government monopoly, which is a more dangerous variant of private monopoly. This fear becomes more pronounced with government's insistence on selling to core investors. This was the cause of the face-off between the Benue State government and the Federal government over the sale of Benue Cement Company to Dangote Industries.

Another fear is that privatisation will cause an increase in prices as government subsidies are removed and the profit motive totally over-rides social responsibility. This fear is greatest on the part of the workers. To them, privatisation means retrenchment, a downward review of conditions of service and insecurity of tenure. Theoretical and empirical analyses show that state ownership suffers from major disadvantages in generating economic surpluses and greater economic efficiency, which are required for rapid and sustained economic growth.

The focus of this paper is to critically examine the privatisation exercise in Nigeria since 1988. It is also the aim of this paper to simplify the complexity in the process of privatisation so as to reduce the probability of crisis. Finally, this paper identifies the impact of privatisation and commercialisation on the performance of enterprises, employment and prices of commodities towards the good governance of the Nigerian society as a whole.

In achieving the above objectives, companies in four industries were used as case studies. These industries are in banking, oil, food and beverages and construction, which were all purposively selected, based on the strategic position and impact of these organisations on Nigeria's economy. Private companies that seem to have almost equal strength as the privatised companies were also used.

\section{Consideration of the conceptual issues involved}

The transfer of ownership from government to the private sector can be done through number of ways. Generally, privatisation may involve non-divestiture and divestiture options. Non-divestiture options include concessions, restructuring and commercialisation joint ventures between public and private enterprises and the contracting out of public services.

Non-divestiture options can help to create the necessary political will and to advance the privatisation process by demonstrating the commercial viability of public enterprises. They may serve as important measures in themselves or as preparatory steps to divestiture (Kwesi, 2000).

Divestiture options are also referred to as privatisation of capital, which involve

(i) direct sale, full or partial, to general investors;

(ii) private placement with strategic investors or to joint venture partners;

(iii) public share offerings on stock markets;

(iv) public auctions (for small enterprises);

(v) management or employee buy-outs (internal privatisation); and

(vi) liquidation followed by sale of assets (where the latter can fetch a higher price than the sale of the entire enterprise on where it may be necessary because of excessive strain on the budget.

In the first set of 55 enterprises privatised in Nigeria as at March, 1993, the following results were obtained:

$\begin{array}{lr}\text { Public offer of shares } & 35 \\ \text { Deferred public offer } & 4 \\ \text { Sales of Assets } & 8 \\ \text { Private placement } & 7 \\ \text { Management Buy-out } & 1\end{array}$

The current privatisation drive favours the use of core investors.

Since the 1970s, privatisation has become a major hallmark of sound economic policy across the world. It is enough to say that privatisation of state-owned enterprises in one form 
or the other has been carried out in most countries of the world over the past three decades. However, no unique approach to it seems to exist yet. This implies that privatisation programmes are country-specific.

In Nigeria, the process began in 1988 and has taken several turns since then. In recent times, as part of the agenda of the present administration, it is again being pursued with renewed vigour. Privatisation is not without controversy; while there seems to be broad agreement on the sale of some enterprises, controversy seems to trail the process and who is buying what is being privatised.

According to Dewan (1991) 'Privatisation has risen from the ashes of the cold war as the most topical issue in the global political economy. It is indeed the new cold war, albeit with totally different battle lines from the old, for privatisation draw opponents as well as proponents from both sides of the iron curtain'.

That privatisation is an issue with an ideological foundation is not in doubt. The proponents of privatisation have continually argued that government should have no part in business activities. The role of government, according to them, should be regulation and control. They believe that privatisation would play an important role in easing commercial activities of state control. The opponents of privatisation are equally forcefully in their criticisms. According to Ezeife (2000), ‘... the present rush-sale of public assets to private interests must be stopped. This is our country, we shall continue to live in it, postprivatisation; no outside pressure should be accepted'. Privatisation according to Waziri (1990), is a conspiracy by a rich and privileged few against the masses, while Kingibe (1997), describe privatisation in Nigeria as the 'systematic stripping by a privileged few of the assets of the people built over the decades'. These hard-line postures come particularly from the dependency and underdevelopment theorists and find backing in the developing countries, which has a very large public enterprises sector.

In the early 1980s, it could have been argued that privatisation was just a product of the political agenda of Margaret Thatcher. However, this does not fit well with recent evidence, which indicated that privatisation has spread to countries with governments of widely different ideologies. It is happening even in countries with left-ofcentre governments such as Russia, Thailand and Vietnam. This suggests that it has been

driven partly by economic forces.

According to Ajiya (1989), 'politically, my research has shown that Nigeria and most of third world governments turn to privatisation out of economic necessity rather than out of big ideological shifts. This, to my mind is a negative approach'. Ajiya is of the opinion that in accepting privatisation as an alternative, efforts should be made to develop a strong ideological foundation for it. This ideological foundation is necessary because privatisation involves the gradual shift from state-centred economies to market-controlled ones, and not just the divestment of interest of government in companies.
The Governor of Central Bank of Nigeria (CBN), Sanusi (2000) supports the economic necessity argument. According to him, 'privatisation has become a topical issue in market economies, given its positive impact on economic management which constitutes a key element of the government budget'.

It is no longer a debate, at least in Nigeria, whether public enterprises are efficient or not. By this, we mean that public enterprises are incontestably inefficient, corrupt and outmoded. The question, however, is 'Is privatisation the panacea to the ebbing performance of public enterprises in Nigeria?' Furthermore, 'what basic advantage will private ownership have over public ownership?' However, since economics (as a discipline) is all about choice among scarce ends that have alternative uses, it is justifiable to ask: ' is there no alternative to privatisation if the genuine concern of the government is public good and improvement of the public enterprises in the country?'

\section{Challenges}

Shonekan, in 2000, cited at the National Conference on Consolidating Democracy in Nigeria several challenges of privatisation, which the government must come to terms with in order to ensure that our country becomes an active participant and beneficiary of the process of privatisation. These include the following:

The first challenge is that of indigenous participation. This can only be guaranteed when there is massive public awareness for the exercise. It is when people are aware that they can actively participate in it. Even where the above condition is met, it is more important to consider the factor of access to funds (with which to participate in the programme for the lower income groups) and equitable spread of participation across geographical regions so that a few ethnic groups are not seen to dominate the exercise and ultimately, the economy of the country in future.

Secondly, the process of privatisation itself must be seen to be open, transparent and above board. Suspicions to the contrary can result in tensions that can destroy the credibility of the privatisation programme. In addition, only an open or transparent process can ensure the emergence of the best investors that can benefit the national economy most. In view of the intrigues and vested interests that characterise it in Nigeria, ensuring transparency poses an enormous challenge to the managers of the process.

The third challenge is that of evolving an effective legal framework and regulatory mechanisms to ensure that privatised enterprises behave in the expected way. This includes non-exploitation of consumers through unjustified inflation of tariffs, particularly where natural monopolies are involved.

Fourthly, there is the challenge of ensuring efficient utilisation of the proceeds of privatisation. Here, there are divergent views. While some analysts have argued that the proceeds should be used to pay off the country's external debts, others argued that they should be invested abroad to cushion the economy against the vagaries of the world oil 
market. A group has also argued that the proceeds should be used to develop social and economic infrastructure.

Fifthly, there is the challenge of having a stable political environment, which can be fostered by good governance. Where the environment is not stable, the process can be characterised by inconsistencies and reversals.

The issue of governance is important because privatisation is an effort to ensure good governance in dependent economies. It is a system that involves managerial and organisational efficiency, accountability, legitimacy, responsiveness to the public and pluralism in policy choice (Oladoyin, 2001:46-48; Olowu \& Erero, 1997:1-20; DFM, 1994: 9-10). Landell-Mills and Serageldin are of the view that

...good governance depends on the extent to which
government is perceived and accepted as
legitimate; committed to improving the public
welfare and responsive to the needs of its citizens;
competent to assure law and order and deliver
public services and able to create an enabling
policy environment for productive activities; and
equitable in its conduct... (Landell-Mills \&
Serageldin, 1992: 310-311)

The ultimate end to which privatisation exercise points, is good governance. This is so for the fact that the Nigerian government sees the exercise as one that would lessen the economic burden of government and increase the participatory role of the public in governance. It is expected that if privatisation is effectively implemented, it will inject some doses of competition into the economic sector; thereby making the society generally virile. In a way, the exercise is also aimed at removing poverty from the Nigerian society. In a way, the privatisation exercise is an experimental effort, a means towards good governance.

\section{Presentation and analysis of findings}

Table 1 shows the proceeds from the first phase of the current privatisation programme. Total proceeds amounted to $¥ 12,66 \mathrm{bn}$ from the eleven companies listed. As figures made available by Financial Derivatives Company Limited showed National Oil Plc shares value topping the list with \#2,782bn. (Sunday Concord, 29 August 1999: 9).

Following National Oil closely is the West African Portland Cement Plc. with \$2,202bn issued shares. Trailing at a distant third is Unipetrol Plc. with its shares currently valued at $\$ 1$,887bn. The best performing banking stock among the Federal Government Agencies on the first list of privatised companies is FSB International Plc at $\$ 1,346 \mathrm{bn}$.

In Table 2 the total proceeds from the second phase of the current privatisation programme amount to $\$ 23,1$ billion from the ten companies listed.

There is a big difference in this figure when compared with the first phase figure where eleven companies were listed. The second phase figure shows a tremendous improvement in the privatisation programme. About $\$ 16,1$ billion was raised through the use of core investors representing $69 \%$ of the total sales proceeds. Proceeds from public offers totalled $\$ 7$ billion representing about $31 \%$ of the sales proceeds. Of the ten companies listed, seven, representing $70 \%$, had core-investors. In one of the companies, Benue Cement Plc. (BCC), all the shares were sold to the core investors. Four of these investors are foreign, representing $57,14 \%$, while three are Nigerian (42,86\%). A foreign investor bought three out of the four cement companies. The result shows a high rate of dependence on foreign investors and core investors generally.

The discrepancies that arise in the area of stock pricing are shown in Table 3. WAPCO's shares were offered for sale at \#,41 more than the NSE listing. Capital gains accruing to government totalled more than $\$ 1$ billion. It would seem from the above that the high prices represent an aim to maximize government's earnings. Although statistics of individual ownership of shares are not available, the view of an anonymous banking consultant interviewed is that these discrepancies will affect share ownership structure because low-income earners will rarely purchase shares above their market prices.

The data of the 15 companies in Table 4 shows that 11 out of the 15 had witnessed an appreciation in the value of their shares. This represents 73,3\%. Seven had percentage increases of above one thousand with the oil companies accounting for the highest appreciation. However, three out of the four insurance companies suffered depreciation of 10 percent. The insurance industry thus seems to have been adversely affected by privatisation.

In Table 5, between 1988 and 1993, the number of shareholders in Nigeria tripled. In percentage terms, it rose from $0,05 \%$ of the population to $1,36 \%$. Between 1993 and 1999 , it increased to $2 \%$ of the population. Statistics also revealed that market capitalisation rose from $\$ 8$ billion to N347 billion in December 1997, before falling to N256billion in 1999. These results show that privatisation has affected positively the growth of the Nigerian capital market. The shareholders population is still very small, however; Britain, with a population of $60,000,000$ people has about 6 million shareholders representing ten percent of the population and $25 \%$ of the adult population (Federal Office of Statistics, 2000).

Table 6 shows the changes in employment in the Nigeria economy. Employment changes in all sectors are examined first before examining changes in the manufacturing sector. The period, 1980 - 1993 shows that employment levels were affected by privatisation in that the exercise, with its attendant downsizing/retrenchment and embargo on public service employment led to marked reduction in the employment rating. The exercise did not spare other sectors although; it is greatest in the public sector. As table 6 shows, the employment rating for the period $1980-1989$ is $11,6 \%$ but it has fallen to $-15,2 \%$ by the period, $1997-1999$. For the private sector, it fell from $2,0 \%$ to $-13,4 \%$, using the same range of periods. These results must however be considered relative to changes in other situations. Between 1989 and 1993, the public sector accounts for more job losses than privatised companies. When privatised firms employment 
rose, public and private sectors still had lower employment levels. It can be concluded that privatisation will affect employment but there are other factors that cause unemployment in the public sector.

The detailed performance of some enterprises privatised in 1992 is shown in Table 7. The 1992 figures show that five out of eight enterprises achieved their set targets. Similarly, results occur in 1993 and 1994. Three enterprises, NEPA, FRCN and NTA did not exceed their targets.

Table 8 shows the movement of prices of commodities produced by four enterprises.

The sharp increase in prices between 1992 and 1994 did not create a sufficient increase in gross earnings for 1994. The results reveal that a reduction in public control did have an effect (at least in the short term) on prices. Profits did increase, but the extent to which this can be attributed to a reduction of government controls is not clear.

In Table 9, public companies with at least $40 \%$ of government control as at 1990 are listed. However, statistics of statutory corporations for the period could not be easily found. Tables 10, 11 and 12 show the trends in ratios in three privatised banks. The date of privatisation for these banks namely, Union Bank, United Bank of Africa (UBA), First Bank Nigeria Plc. is 1992. With this, it is possible to begin to attribute changes to privatisation from 1993. In other words, the period when the dividend of privatisation can begin to manifest in the listed banks is 1993 and beyond. The results show that debt ratio remains fairly constant in excess of ninety percent (90\%) before and after privatisation. Investment in Total Assets follows a random pattern. For First Bank, it begins to reduce after privatisation while for UBA, it increases rapidly. It also follows the same pattern in Union Bank (i.e. a fluctuation pattern). The profit to Total Assets thus becomes our guideline.

The three banks witnessed sharp increases in investments and profitability immediately after privatisation, and there was a slight decrease before another increase. How much of these changes should be attributed to a change of ownership may be difficult to determine, but it may be inferred that privatisation has a part to play in these changes.

\section{Summary, conclusion and recommendations}

The aim of this study is to determine the effects of privatisation on company performance, prices and employment. Key issues and areas in privatisation such as stock pricing have been examined.

Results show that privatisation has improved to an appreciable extent, company performance, especially in the aspect of efficiency of resources utilisation. Higher profits to capital employed ratios have been witnessed since privatisation. Debts, as well as total asset ratios have not been much affected; hence, it is not likely that high or low debt ratios will affect efficiency.
Results also reveal that price increases in excess of $200 \%$ occurred immediately after privatisation. This, no doubt had effect on the profits of the companies (especially those that still maintained monopoly status for a while). How much these price increases have affected perceived privatisation gains cannot be known for certain.

The likely effects of privatisation such as, offering the country's assets for sale to the rich few; perpetuation of social inequality; rise in unemployment and increase in mass poverty had been a major fear. Results however show that privatisation did cause an increase in employment levels. Compared to employment changes generally, this outcome is not as bad as had been anticipated. Changes similar to, and sometimes worse than what obtains in the privatised firms were recorded in public firms also. For instance, the rate of fluctuation in unemployment for the public sector fell from $11,6 \%$ in the period between $1980-1989$ to $-15,2 \%$ in the period between 1997, whereas the fluctuation for privatised companies ranged between $3.1 \%$ in the period between 1980 and 1989, and $-6,4 \%$ in the period between 1997 and 1999 (Federal Office of Statistics, 2000). Another factor that affected employment such as the desire to improve efficiency of which privatisation may be a tool was also observed.

Privatisation in Nigeria has its problems. There is a high tendency that privatisation will boost governments' revenue. In this connection, discrepancies in stock pricing were noticed. This may prove to be a deterrent to prospective shareholders. It was also clear that foreign participation is very high. The benefits or disadvantages of this cannot be statistically determined. Share ownership is still very low; and less than $2 \%$ of the population own shares.

At any rate, privatisation has come to stay in Nigeria. In spite of the public sentiments expressed in the media and public debates against such agenda, the government of Nigeria was deviant and against all odds pursued the programme. It is a programme in the direction of globalisation, which the government had little or no power to resist. Following the globalisation arguments and removing the impediments of human frailty, the programme has the prospect of improving the country's economic wellbeing and consequently enhances good governance. This suggests that the programme has to be pursued according to specific guidelines to achieve desired objectives, which should be clear. It must be stated, however, that privatisation is not a panacea to all the problems of public ownership. It is a means to an end but not an end in itself. Therefore, to enable those implementing privatisation to overcome the challenges, the following measures are recommended:

(i) In offering shares for sale, the process should be supervised by the stock exchange. This will prevent discrepancies that allow confusion to occur.

(ii) Share ownership should be carefully monitored. Government should liaise with banks to finance loans at low rates to encourage participation. The core investor issue should be carefully looked into. 
(iii) Government should retain 'golden shares' in privatised companies to prevent external take-over bid.

(iv) Pre-privatisation agreements between governments and these companies should be enforced.

(v) The principle of social justice needs to be applied in privatisation.

(vi) Every privatisation decision should be preceded by a specific feasibility analysis and this must be followed by analysis of the social impact or the social cost or benefits or privatisation.

In spite of the above recommendations, a number of challenges are still likely to be encountered by newly privatised firms. One of these is about how to develop adequate management capabilities especially in the areas of market analysis cost assessment and quality assurances. Another challenge relates to the orientation of management in which case, employees in newly privatised firms may require extensive employee training to make them fit in a modern private sector.

\section{References}

Ajiya, R. 1989. 'Privatisation in Nigeria', New Nigeria, 14 August: 7.

Akin, I. 2002. 'Privatisation and economic development'. Quoted in Sunday Punch, 17 March 45.

Ariyo, A. \& Jerome, A. 1999. 'Privatisation in Africa: An appraisal', World Development, 27:1

Bureau of Public Enterprises (BPE). 1995. Seventh Annual Report and Audited Accounts 1994 and 1995. www.bpeng.org.

Bureau of Public Enterprises (BPE). 2000. 'Proceeds of privatisation' Vanguard 10 November: $15-16$

Bureau of Public Enterprises (BPE). 2001. - Quoted from www.bpeng.org.

CBN 1995. Annual reports and Statement of Account. Abuja, Central Bank of Nigeria.

Campbell-White, O. 2000. Quoted in 'Privatisation in Africa: Issues and Challenges', Financial Standard, 4 December:28.

Dewan, P. 1991. 'Privatisation - The British experience', The Guardian, 3; 4; 5 May, 1999: 49; 61; and 49.

DFM, USAID. 1994. 'Governance Initiative in Nigeria: A Strategic Assessment of Primary Health care and Local Government', Associates in Research Development Inc. (ARD).

Duru, C. 2000. 'Privatisation, democracy and law', The Guardian, 22 October: 51.
EFA Monitoring Report 2005. 'Education for all: The quality imperative’, Paris: UNESCO.

El-Rufai. 2000. 'Bureau ill-equipped to handle privatisation’, The Punch, 29 June: 2.

El-Rufai. 2000. 'Privatisation to fetch government $\$ 15$ billion, The Guardian, 30 June:19.

El-Rufai. 2000. 'Privatisation: We prefer to build local capitalism', This Day, 19 July, 26(1914):29.

Ezeife, C.P. 2000. This privatisation? The Punch, 12 August: 12

Federal Office of Statistics. 2000. Annual Abstracts of Statistics, Abuja: Federal Office of Statistics.

FBN. 1996. Financial and Annual Reports 1988-96. Lagos, First Bank of Nigeria Plc: 20.

Ijewere, E. 2000. Quoted in NNPC BPE 'Disagree on sale of oil firms’, The Guardian, 31 May 31:57.

Ikhinmwin, E. 2000. 'Conflicts in stock pricing and privatisation’, The Guardian, 31 May: 33.

Jenkinson, T.J. \& Mayer, C.M. 1988. 'The privatisation process in France and U.K', European Economic Review, 34: $482-490$.

Kay, J. \& Thompson, D. 1986. 'Privatisation - A policy in search of rationale', Economic Journal, 96:18 - 32.

Kere-Ekun. 2000. 'Privatisation council to assist workers get shares', The Guardian, 29 March:18.

Kingibe, B. 1997. 'Privatisation in Africa', The Guardian, 30 September: 21.

Kwesi, P. 2000. 'Privatisation and commercialisation of public enterprises - An alternative view point'. Paper read at the All Peoples Party Summit, Abuja, 9-10 November.

Landell-Mills, P. \& Serageldin, I. 1992. 'Governance and the external factor'. Proceedings of the World Bank Conference Development Economics. Washington: World Bank.

Lipsey, R. G. \& Chrystal, K. A. 1995. Introduction to positive economics. $8^{\text {th }}$ Edition. Oxford : Oxford University Press.

NSE. 1990. Financial statements in the Stock Exchange, Lagos: Nigeria Stock Exchange.

NSE. 1999. Annual reports. Lagos: Nigeria Stock Exchange.

Obadan, M. \& Ayodele, A. 1999. The commercialisation and privatisation policy in Nigeria. Ibadan: NCEMA.

Ogbimi, F. 1997. 'Before we privatise Nigeria', The Guardian, 5 May: 23. 
Oladoyin, A.M. 2001. 'Indigenous governance and the management of conflict and stability in the multi-ethnic community of Ilorin.' Unpublished Ph.D thesis, Department of Public Administration, Obafemi Awolowo University, Ile-Ife, Nigeria.

Olowu, D. \& Erero, J. (Eds.). 1997. Indigenous governance systems in Nigeria. Ile-Ife: LISDP.

Pandey, I. M.1999. Financial management. $8^{\text {th }}$ Edition. New Delhi: Vikas.

Sanusi, J. 2000. 'Sanusi apprehensive of privatisation', The Punch, 16 June: 15.

Shonekan, E. A.O. 2000. 'Challenges of globalisation and privatisation in Nigeria’, This Day, 10 July :48 - 49.

Smith, A. 1776. 'Quoted in privatisation and economic development', Sunday Punch, 17 March, 2002:45.

Sunday Concord. 1999. 'Financial derivatives company limited', 29 August:9.

UBA. 1996. Financial and Annual Reports 1990-96. Lagos, United Bank for Africa Plc: 22.

UBN. 1996. Financial and Annual Report 1990-96. Lagos, Union Bank of Nigeria Plc: 25.

Veljanovski, C.G. 1991. Industrial privatisation in Africa. World Bank Report. Washington: D.C: World Bank.

Waziri, M. 1990. 'Peoples right \& privatisation', National Concord, 5 March: 7.

Wilson, E. 1986. 'Privatisation in Nigeria', The Guardian, 6 June:20.

Wright, V. 1991. The politics of industrial privatisation in Western Europe: Pressures, problems and paradoxes, London: Longman. 
APPENDICES

TABLE 1:PROCEEDS OF PRIVATISATION (First Phase)

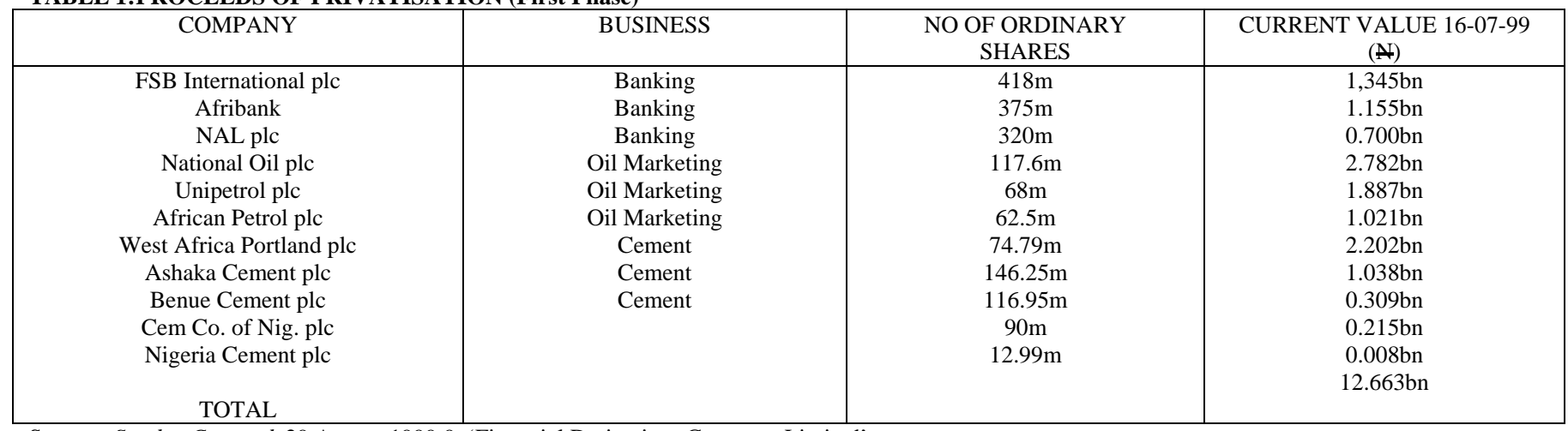

Source: Sunday Concord, 29 August 1999:9. 'Financial Derivatives Company Limited’.

TABLE 2:PROCEEDS OF PRIVATISATION (Second Phase)

\begin{tabular}{|c|c|c|c|c|c|}
\hline COMPANY & CORE INVESTOR & $\begin{array}{c}\text { AMOUNT } \\
\text { OF SHARE } \\
\text { BOUGHT } \\
\text { (N) }\end{array}$ & $\begin{array}{l}\text { AMOUNT } \\
\text { PAID } \\
\text { (N) }\end{array}$ & $\begin{array}{c}\text { PUBLIC } \\
\text { OFFER } \\
\text { PROCEED } \\
\text { (N) }\end{array}$ & $\begin{array}{l}\text { TOTAL } \\
\text { (N) }\end{array}$ \\
\hline Ashaka cement plc & Blue Circle industrial plc U.K. & 146250 & $1,572,187,500$ & $500,926,115.51$ & $2,073,113,615.5$ \\
\hline WAPCO & Blue Circle industrial plc UK & $55,340,000$ & $1,789,550,080$ & $1,085,551,357.5$ & $2884,107,557.5$ \\
\hline Benue cement Company plc & Dangote Industry Ltd. & $173,267,194$ & $918,316,128$ & Nil & $918,316,128$ \\
\hline Unipetrol Nig. plc & Ocean and Oil Nigeria Ltd. & $46,875,000$ & $1,593,750,000$ & $453,125,000.1$ & $2,046,875,000$ \\
\hline CCNN & Scarncern Norway & $154,915,741$ & $622,701,278.12$ & $559,340,25$ & $678,695,303.82$ \\
\hline FSB Int'l & Nil & Nil & Nil & $1,598,529,219$ & $1,598,529,219$ \\
\hline IMB & Nil & Nil & Nil & $14,396,764.5$ & $14,396,764.5$ \\
\hline NAL Merchant Bank & Nil & Nil & Nil & $1,153,438,550$ & $1,153,438,550$ \\
\hline NOLCHEM & CON Petro & $219,520,000$ & $7,412,916,000$ & $1,472,000,000$ & $8,894,916,000$ \\
\hline African Petroleum & Sadiq Petroleum & $64,800,000$ & $2,308,400,000$ & $615,600,00$ & $2,924,000,000$ \\
\hline TOTAL & & & & & $23,176,387,938,22$ \\
\hline
\end{tabular}

Source: Vanguard, 10 November , 2000:15-16. Bureau of Public Enterprises.

TABLE 3: STOCK PRICING (First Phase)

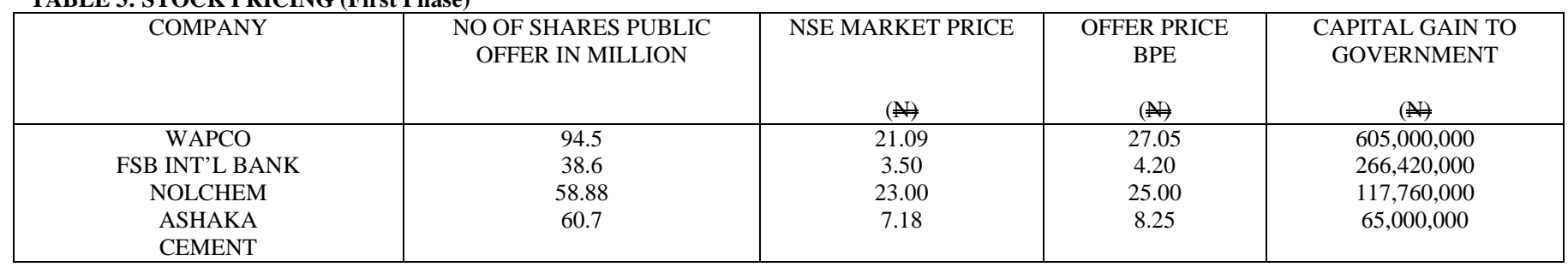

Source: Calculations from NSE Reports, 1999 .

TABLE 4: STOCK PRICING (Second Phase)

\begin{tabular}{|c|c|c|c|c|c|}
\hline $\begin{array}{c}\text { PRIVATISED } \\
\text { COMPANY }\end{array}$ & DATE OF OFFER & $\begin{array}{c}\text { OFFER PRICE } \\
\text { (\#) }\end{array}$ & $\begin{array}{c}\text { MARKET PRICE } 1997 \\
\text { (N) }\end{array}$ & $\begin{array}{c}\text { PERCENTAGE } \\
(\%)\end{array}$ & $\begin{array}{c}\text { CAPITAL } \\
\text { APPRECIATION } \\
(\%)\end{array}$ \\
\hline National Oil & $8-5-89$ & 2.00 & 58.18 & 2909 & 56.18 \\
\hline African Petroleum & $27-2-90$ & 1.90 & 56.00 & 2947 & 54.10 \\
\hline Ashaka cement & $5-2-90$ & 1.20 & 13.80 & 1150 & 12.60 \\
\hline Benue cement & $20-8-90$ & 0.90 & 6.0 & 666 & 5.10 \\
\hline Flour mils Nig.plc & 3-12-89 & 0.80 & 11.50 & 1437.5 & 10.70 \\
\hline Afri Bank Nig plc & 11-1-93 & 1.20 & 6.0 & 500 & 4.80 \\
\hline First Bank Nig plc & $6-11-92$ & 2.00 & 14.50 & 725 & 12.50 \\
\hline FSB Int'L Bank & 24-5-92 & 0.70 & 8.60 & 1228.6 & 7.90 \\
\hline Union Bank plc & $7-12-92$ & 1.00 & 12.50 & 1250 & 11.50 \\
\hline Unipetrol & $27-5-91$ & 2.00 & 73.10 & 3655 & 71.10 \\
\hline WAPIC & 6-11-89 & 1.10 & 0.99 & 90 & $(0.11)$ \\
\hline Sun Insurance & 3-10-89 & 1.25 & 1.23 & 98.4 & $(0.02)$ \\
\hline Savannah Bank & 4-1-93 & 1.00 & 0.64 & 64 & $(0.31)$ \\
\hline Guinea Ins. Plc & 6-11-89 & 0.80 & 0.88 & 110 & 0.08 \\
\hline NEM Insur. Plc. & 6-11-89 & 1.15 & 1.16 & 100.87 & 0.01 \\
\hline
\end{tabular}

Source: Nigeria Stock Exchange. Quoted from Obadan \& Ayodele, 1999. 
TABLE 5: SHAREHOLDERS STATISTICS

\begin{tabular}{|c|c|c|c|}
\hline YEAR & NO. OF SHAREHOLDERS & POPULATION (million) & 80 \\
\hline 1988 & 400,00 & 88 & PERCENTAGE \\
1993 & $1,200,00$ & 0.05 \\
1999 & $2,000,000$ & 1.36 \\
2 & \\
\hline
\end{tabular}

Source: Federal Office of Statistics, 2000 . These figures are approximated.

TABLE 6: FLUCTUATION IN EMPLOYMENT

\begin{tabular}{|l|c|c|c|}
\hline TYPE OF FIRM (ALL SECTORS) & $\begin{array}{c}1980-1989 \\
(\%)\end{array}$ & $\begin{array}{c}1989-1993 \\
(\%)\end{array}$ & $\begin{array}{c}1993-1997-1999 \\
(\%)\end{array}$ \\
\hline Public & 11.6 & -9.7 & -6.1 \\
Privatised & 3.1 & -4.0 & 5.1 \\
Private & 2.0 & -8.7 & 1.5 \\
Manufacturing Sector & & -6.4 & \\
Public & 2.2 & -6.7 & -7.1 \\
Privatised & 2.1 & -14.3 & -15.4 \\
Private & 2.2 & -10.6 & -14.7 \\
\end{tabular}

Source: Federal Office of Statistics, 2000

TABLE 7: PERFORMANCE OF SOME COMMERCIALIZED PUBLIC ENTERPRISES AS PER GROSS EARNINGS IN \# BILLION

\begin{tabular}{|c|c|c|c|c|c|c|}
\hline \multirow{2}{*}{$\begin{array}{c}\text { PUBLIC } \\
\text { ENTERPRISES }\end{array}$} & \multicolumn{2}{|c|}{1992} & \multicolumn{2}{|c|}{1993} & \multicolumn{2}{|c|}{1994} \\
\hline & TARGET & ACTUAL & TARGET & ACTUAL & TARGET & ACTUAL \\
\hline NICON & 0.38 & 0.77 & 0.41 & 1.17 & 0.46 & 1.53 \\
\hline NSPSC & 0.62 & 1.16 & 0.67 & 1.38 & 0.71 & 1.93 \\
\hline NITEL & 4.34 & 6.37 & 5.49 & 10.13 & 6.16 & 12.97 \\
\hline NAA & 0.19 & 0.35 & 0.20 & 0.70 & 0.21 & 1.10 \\
\hline NSTF & 0.28 & 1.22 & 0.81 & 1.29 & 1.09 & 1.10 \\
\hline NEPA & 3.15 & 0.03 & 9.53 & 4.82 & 10.15 & 7.45 \\
\hline FRCN & 0.06 & 0.05 & 0.07 & 0.07 & 0.08 & 0.07 \\
\hline NTA & 0.15 & 0.22 & 0.28 & 0.28 & 0.24 & 0.42 \\
\hline
\end{tabular}

Source: Bureau of Public Enterprises. 1995. Seventh Annual Reports and Audited Accounts 1994/1995. www.bpeng.org

\begin{tabular}{|c|c|c|c|c|c|c|c|c|c|}
\hline $\begin{array}{c}\text { PUBLIC } \\
\text { ENTERPRISES }\end{array}$ & PRODUCT & UNIT & $\begin{array}{c}1985 \\
(\#)\end{array}$ & $\begin{array}{c}1989 \\
(\$)\end{array}$ & $\begin{array}{c}1990 \\
(\#)\end{array}$ & $\begin{array}{c}1991 \\
(\$)\end{array}$ & $\begin{array}{c}1992 \\
\text { (W) }\end{array}$ & $\begin{array}{c}1994 \\
\text { ( })\end{array}$ & $\begin{array}{c}1994=\text { INDEX } \\
1995=100\end{array}$ \\
\hline NEPA & Elect & KWh & 0.06 & 0.11 & 0.29 & 0.32 & 0.32 & 0.53 & 883 \\
\hline NNPC & $\begin{array}{c}\text { LPG } \\
\text { PMS } \\
\text { Kerosene } \\
\text { Fuel Oil }\end{array}$ & $\begin{array}{l}13 \mathrm{~kg} \\
\text { litre } \\
\text { litre } \\
\text { litre }\end{array}$ & $\begin{array}{c}5.00 \\
0.20 \\
0.15 \\
30.00\end{array}$ & $\begin{array}{c}8.00 \\
0.40 \\
0.15 \\
30.00\end{array}$ & $\begin{array}{c}80.00 \\
0.70 \\
0.50 \\
35.00\end{array}$ & $\begin{array}{c}120.00 \\
0.70 \\
0.50 \\
35.00\end{array}$ & $\begin{array}{c}120.00 \\
0.70 \\
0.50 \\
35.00\end{array}$ & $\begin{array}{c}250.00 \\
11.00 \\
9.00 \\
85.00\end{array}$ & $\begin{array}{c}5000 \\
5000 \\
6000 \\
28333\end{array}$ \\
\hline NITEL & $\begin{array}{c}\text { Sorn } \\
\text { RW/W } \\
\text { Telex }\end{array}$ & Pulses & 0.10 & 0.10 & 0.90 & 0.90 & 0.90 & 5.00 & 5000 \\
\hline NIPOST & $\begin{array}{c}\text { Postal Services } \\
\text { Registration }\end{array}$ & Postal & $\begin{array}{l}0.2 \\
0.5\end{array}$ & $\begin{array}{l}0.5 \\
1.5\end{array}$ & $\begin{array}{l}0.50 \\
1.5\end{array}$ & 0.50 & 0.50 & $\begin{array}{l}5.00 \\
30.00\end{array}$ & $\begin{array}{l}2500 \\
6000\end{array}$ \\
\hline
\end{tabular}

Source: CBN Annual Reports and Statement of Account 1985 - 1995

TABLE 9: RETURN OF CAPITAL EMPLOYED (ROCE) RATIO OF SELECTED COMPANIES (1990)

\begin{tabular}{|c|c|c|}
\hline \multicolumn{2}{|c|}{ PRIVATE COMPANIES } & \multicolumn{2}{c|}{ POMPANY COMPANIES } \\
\hline COMPANY & ROCE (\%) & BCC \\
\hline G'CAPPA PLC & 30.7 & NIGERIAN FLOUR MILLS \\
CADBURY PLC & 45.8 & NOLCHEM \\
CAPPA & 273 & AFRICAN PETROLEUM \\
D'ALBERTO PLC & 19.60 & WAPCO \\
JULIUS BERGER & 34.4 & UNIPETROL \\
PLC & 261 & CNCC \\
UNION DICON & 392 & ASHAKA CEMENT \\
COSTAIN & 243 & \\
NTC & 16.40 & 14.3 \\
CHEVERON PLC & 143 & 17.8 \\
\end{tabular}

Source: Calculated from Financial Statements in the Stock Exchange, 1990. 
TABLE 10: TREND ANALYSIS OF RATIOS IN PRIVATISED BANKS

FIRST BANK NIGERIA PLC

\begin{tabular}{|c|c|c|c|}
\hline \multirow{2}{*}{ YEAR } & DEBT TO TOTAL ASSETS & $\begin{array}{c}\text { INVESTMENT TO TOTAL } \\
\text { ASSETS } \\
(\%)\end{array}$ & $\begin{array}{c}\text { PROFIT TOTAL TO ASSETS } \\
(\%)\end{array}$ \\
\hline 1988 & $(\%)$ & 1.25 & 1.05 \\
1989 & 93.8 & 0.98 & - \\
1990 & 93.7 & 1.02 & - \\
1991 & 96.4 & 0.73 & 1.97 \\
1992 & 95.9 & 0.50 & 2.48 \\
1993 & 94.3 & 0.38 & 1.63 \\
1994 & 93.6 & 0.34 & 1.38 \\
1995 & 94.6 & 0.25 & \\
1996 & 90.3 & 0.24 & 1.36 \\
\hline
\end{tabular}

Source: FBN Financial and Annual Reports, 1988-1996.

TABLE 11: UNITED BANK OF AFRICA (UBA)

\begin{tabular}{|c|c|c|c|}
\hline YEAR & DEBT TO TOTAL ASSETS & $\begin{array}{c}\text { INVESTMENT TO TOTAL } \\
\text { ASSETS } \\
(\%)\end{array}$ & 0.078 \\
$(\%)$
\end{tabular}

Source: UBA Financial and Annual Reports, 1990 - 1996.

\begin{tabular}{|c|c|c|c|}
\hline YEAR & $\begin{array}{c}\text { DEBT TO TOTAL ASSETS } \\
(\%)\end{array}$ & $\begin{array}{c}\text { INVESTMENT TO TOTAL } \\
\text { ASSETS } \\
(\%) \\
\end{array}$ & $\begin{array}{c}\text { PROFIT TO TOTAL ASSETS } \\
(\%)\end{array}$ \\
\hline 1990 & 91 & 0.18 & 1.03 \\
\hline 1991 & 95 & 0.30 & 0.06 \\
\hline 1992 & 94.8 & 0.26 & 0.35 \\
\hline 1993 & 94.75 & 0.24 & 1.41 \\
\hline 1994 & 95.35 & 0.18 & 0.96 \\
\hline 1995 & 95.4 & 0.05 & 0.75 \\
\hline 1996 & 94.7 & 0.05 & 1.35 \\
\hline
\end{tabular}

Source: Union Bank Financial and Annual Reports, 1990 -1996. 